\title{
ALASAN DAN LANGKAH PEMBANGUNAN BISNIS BERBASIS WEB
}

\author{
Idris Gautama ${ }^{1}$
}

\begin{abstract}
This paper starts with the explanation of e-Commerce, e-Business, types of business, and taxonomy of business models. This paper also explains why starting web-based business from scratch is easier than to transform brick and mortal business to web-based/internet business. Then step-by-step creating web-based business will be explained.
\end{abstract}

Keywords: business, web

\section{ABSTRAK}

Artikel ini dimulai dengan penjelasan mengenai e-Commerce, e-Business, tipe bisnis, dan taksonomi model bisnis. Dalam artikel ini juga dijelaskan mengapa memulai bisnis berbasis web dari scratch lebih mudah daripada dari transform brick and mortal business ke webbased/internet business.

Kata kunci: bisnis, web

\footnotetext{
${ }^{1}$ Staf Pengajar Fakultas Ilmu Komputer, UBiNus, Jakarta
} 


\section{PENDAHULUAN}

Banyak pengertian tentang e-Commerce dan $e$-Business yang diberikan oleh pengarang buku. Dalam artikel ini yang dimaksud dengan e-Commerce adalah semua perusahaan yang menggunakan internet dalam bisnisnya sedangkan $e$-Business adalah individu perusahaan yang menggunakan internet dalam bisnisnya (Reding, 2001:4). Bisnis baik yang tradisional maupun yang menggunakan internet dapat dikategorikan dalam dua jenis sebagai berikut.

1. Bisnis Produk

2. Bisnis Jasa

Bisnis Produk adalah bisnis yang menjual produk dalam transaksinya sedangkan bisnis jasa adalah bisnis yang menjual pengetahuan dan keahlian. Sebagai contoh, perusahaan dagang adalah adalah jenis binis produk sedangkan konsultan adalah jenis bisnis jasa. Taksonomi dapat diartikan sebagai pengkategorian sedangkan model dalam ilmu pengetahuan adalah hipotesis tentang hubungan sebab-akibat dan dalam arsitektur adalah representasi gaya struktur yang direncanakan, demikian juga model bisnis menjalankan tujuan yang sama (Eisenmann, 2002:xii).

\section{PEMBAHASAN}

\section{Landasan Teori}

\section{Taksonomi Model Bisnis}

Berdasarkan pendapatannya, model bisnis dapat diikhtisarkan dalam 7 model (Afuah, 2003:104-117) sebagai berikut.

\section{Commision}

Ide dasarnya adalah penambahan biaya pada transaksi berdasarkan besarnya tranksaksi yang dilakukan. Disini komisi yang diterima oleh perusahaan sebagai perantara menjadi pendapatan utama. Contoh perusahaan jenis ini adalah $e$-Bay.

\section{Advertising}

Ide dasarnya adalah end user disubsidi oleh iklan. Di sini perusahaan pemilik web-site menyediakan end-user fasilitas tersubsidi atau gratis atas isi, jasa, atau bahkan produk untuk menarik end-user. Contoh perusahaan jenis ini adalah Yahoo. Yahoo mewakili perusahaan yang menyediakan jasa untuk orang sebanyak-banyaknya agar mereka menjadi pemirsa dari iklan yang layaknya ditayangkan di media massa sedangkan dapat saja perusahaan memfokuskan pada pelanggan yang ditargetkan sebelumnya.

\section{Mark Up}

Ide dasarnya adalah adanya penambahan nilai pada penjualan. Di sini penambahan nilai (mark-up) dilakukan karena perusahaan memiliki sejumlah keunggulan sehingga pelanggan yang tertarik untuk membeli dari perusahaan. Contoh bisnis jenis adalah melakukan lelang atau karena keunggulan efisiensi distribusi dapat menambah nilai penjualan seperti Amazon. 
4. Production

Ide dasarnya adalah adanya penambahan nilai pada produksi. Biasa juga dikenal sebagai Model Pabrikan (Manufacturing Model), bisnis ini digunakan oleh kalangan perusahaan yang memproduksi barang dan langsung dikenalkan kepada pelanggan melalui internet/web. Contoh perusahaan yang menggunakan model ini adalah Compaq yang langsung menjual chip memory kepada pelanggan melalui internet/web.

5. Referral

Ide dasarnya adalah biaya kerena memperkenalkan (referring) pelanggan pada suatu bisnis. Pada bisnis jenis ini perusahaan membayar kepada pelanggan sejumlah nilai yang telah disepakati sebelumnya (dapat berdasar nilai yang rata atau proporsional) karena pelanggan telah memperkenalkan bisnis perusahaan pada pelanggan lainnya. Bisnis jenis ini mendapat rating 5/5 (terbaik) oleh Bradey J. Sugars (Sugars(2), 2000:66-67). Contoh perusahaan yang menggunakan model ini dalam bisnisnya adalah Goldquest.

6. Subscription

Ide dasarnya adalah biaya utuk penggunaan tak terbatas. Perusahaan mengenakan suatau biaya tetap / rata pada suatu periode kepada pelanggan untuk suatu jasa yang diberikan. Biaya ini tetap dikenakan baik jasa perusahaan dipakai maupun tidak oleh pelanggan. Contoh perusahaan yang menggunakan model ini pada bisnisnya adalah AT\&T Worldnet.

7. Fee-for-service

Ide dasarnya adalah pelayanan yang diukur. Di sini jasa yang dipergunakan oleh pelanggan diukur dan dijadikan sebagai dasar pembebanan kepada pelanggan yang bersangkutan. Contoh perusahaan pada model bisnis ini adalah Corio yang membebankan/menyewakan aplikasi perangkat lunak pada berbagai perusahaan.

Taksonomi yang dijelaskan di atas dijelaskan secara bervariasi pada berbagai literatur, sebagai contoh dikategorikan menjadi 8 oleh Eisenmann (Eisenmann, 2002:xii) namun inti pembahasan literatur yang ada adalah seperti yang dijelaskan di atas.

\section{Perusahaan Brick and Mortal Versus Perusahaan Berbasis Web}

Perusahaan Brick and Mortal adalah perusahaan tradisional dan pelanggan melakukan kegiatan didalam gedung atau toko (Reding, 2001:4) sedangkan perusahaan berbasis web dapat saja tidak memiliki toko atau gedung real. Banyak perusahaan Brick and Mortal seperti Toy-R-Us, Merril Lynch, dan Barnes and Noble yang lambat dalam bergerak ke arah online dengan berbagai alasan termasuk di dalamnya sebagai berikut (Eisenmann, 2002:ix).

1. Perhatian pada kemungkinan kanibalisasi atas unit online terhadap perusahaan tradisionalnya.

2. Perhatian pada dampak harga saham karena membiayai pengeluaran (losses) Internet.

3. Lamban dan bahkan sering disfungsionalnya proses pengambilan keputusan pada perusahaan yang telah mapan khususnya kegagalan analisis discounted-cash-flow tradisional dalam menunjang strategi yang menghasilkan profit pada perusahaan.

Karena pertimbangan di atas, banyak perusahaan yang memisahkan unit internetnya dari unit intinya. Unit internetnya bahkan adalah unit yang baru sama sekali dari sisi personilnya dan mereka diberi mandat untuk mengkanibal unit intinya (Eisenmann, 2002:ix). Bahkan, banyak ahli berpendapat adalah lebih mudah memulai perusahaan e-Business dari awal dibanding dengan 
menyesuaikan perusahaan Brick and Mortal karena belum adanya kebiasaan yang harus diubah dan belum adanya pelanggan yang harus dipindahkan ke tempat baru (Reding, 2001:6).

Dengan memperhatikan pendapat di atas, sangat bijaksana apabila dalam pertimbangan pembuatan perusahaan dan bisnis baru memasukan $e$-Business dalam pertimbangan utamanya, terutama bila bisnis yang dilakukan dapat memenuhi model bisnis yang telah dibahas di atas.

\section{Langkah Pembangunan e-Business}

1. Mengerti hal penting dalam bisnis berbasis web-based/internet.

a. Bagaimana tujuan dan kebutuhan bisnis didefinisikan.

b. Alasan diadakannya Web.

c. Mengerti istilah penting dalam Web/internet, misalnya web-page, homepage, hyperlink, browser, portal, dan lainnya.

d. Bagaimana menemukan informasi di Web. Hal itu akan membantu sehingga nantinya web yang dibangun sudah memperhatikan aspek ini.

e. Perangkat lunak yang dibutuhkan untuk pengelolaan surat elektronik.

f. Bagaimana mengakhiri suatu sesi web.

2. Membuat rencana bisnis.

a. Alasan dibutuhkannya rencana bisnis. Hal itu terutama mempertimbangkan pihak terkait (stake holder) perusahaan, misalnya bank, penanam modal, mitra bisnis, perekrutan karyawan, dan karyawan yang telah ada.

b. Membuat Ringkasan Eksekutif. Hal itu biasanya terdiri dari satu sampai 3 halaman yang merupakan ringkasan dari konsep bisnis, aspek finansial, kebutuhan finansial, situasi bisnis terakhir dan awal.

c. Membuat rencana bisnis lengkap, (Reding, 2001:29) yang terdiri dari sebagai berikut.

i. Pendahuluan.

Berisi halaman sampul, daftar isi, dan Ringkasan Eksekutif.

ii. Deskrisi bisnis.

Menyediakan pandangan singkat tentang industri saat ini dan mendatang, menampilkan misi, mendefinisikan produk dan jasa, mendeskripsikan posisi perusahaan dalam pasar, dan membuat daftar strategi harga.

iii. Pasar

Menjelaskan target pelanggan, mendefinisikan ukuran pasar menyeluruh dan pasar sasaran, membuat daftar pesaing dengan penjelasannya, dan memprakirakan penjualan.

iv. Pengembangan dan Produksi.

Menjelaskan status produk/jasa, proses produksi, menyediakan informasi anggaran perancangan dan pengembangan, menjelaskan secara ringkas kebutuhan tenaga kerja, dan mencantumkan biaya operasi, kebutuhan barang modal, dan harga pokok.

v. Penjualan dan Pemasaran.

Menjelaskan cara mendapatkan pelanggan potensial dan menjadikannya pelanggan, definisikan saluran distribusi dan jelaskan secara singkat iklan dan kampenye promosi yang akan dilakukan.

vi. Manajemen.

Menjelaskan secara singkat pemilik dan pengelola perusahaan, menggambarkan struktur organisasi dan dewan direksi, serta menentukan jasa pendukung. 
vii. Informasi Keuangan.

Menilai risiko finansial, menyediakan dan menganalisis laporan arus kas, neraca, laporan laba rugi, dan mengestimasi kebutuhan pendanaan.

3. Membuat rencana pemasaran.

a. Alasan dibutuhkannya rencana pemasaran.

Rencana bisnis mengikhtisarkan perusahaan keseluruhan, rencana pemasaran menjelaskan bagaimana mencapai tujuan perusahaan.

b. Membuat Ringkasan Eksekutif.

Ini berisi sinopsis strategi pemasaran.

c. Membuat Rencana Pemasaran, (Reding, 2001:48) yang biasanya terdiri dari hal berikut.

i. Pendahuluan.

Berisi halaman sampul, daftar isi, Ringkasan Eksekutif.

ii. Analisis Situasional.

Menjelaskan permintaan dan kecenderungan dalam lingkungan, menentukan posisi dalam industri, menjelaskan dampak kelompok atau organisasi, menjelaskan persaingan, mendefinisikan lingkungan dalam organisasi.

iii. Pelanggan Sasaran.

Menentukan demografi pelanggan, memerinci kebiasaan pembelian pelanggan, dan mengetahui keinginan pelanggan.

iv. Taktik Pemasaran.

Membuat daftar bagaimana mendapatkan pelanggan sasaran, menjelaskan metode pemasaran, memerinci bauran pemasaran, dan menjelaskan bagaimana menjalankan perencanaan.

v. Anggaran Pemasaran.

Menentukan jumlah uang yang dubutuhkan, dan menjelaskan bagaimana mencapai tujuan keuangan ini.

vi. Ringkasan.

Mendiskusikan alasan-alasan bahwa rencana yang dibuat dapat dicapai.

4. Membangun Web untuk bisnis.

a. Menentukan Perangkat Lunak yang akan digunakan.

Dalam menentukan penggunaan perangkat lunak, hendaknya dipilih yang banyak tersedia di pasar sehingga memudahkan pemeliharaannya. Selain itu, juga dipilih yang userfriendly. Perangkat lunak yang banyak digunakan dan relatif sederhana adalah Microsoft FrontPage, Adobe SiteMill, Claris HomePage, Lotus FastSite. Penguasaan HTML juga sangat dianjurkan

b. Mempelajari penggunaan Perangkat lunak.

Penguasaan perangkat lunak yang dipilih sekarang banyak tertolong dengan fitur bantuan (help) yang disediakan perangkat lunak. Bahkan sekarang banyak perangkat lunak tutorial untuk mempelajari perangkat lunak tertentu.

c. Mempelajari desain grafis.

Dengan menguasai desain grafis akan membuat ketertarikan orang pada web yang dirancang menjadi lebih baik. Dalam hubungan dengan perancangan web maka penggunaan form, frame, hyperlink, penambahan search engine bila perlu, serta aspek terkait lainnya perlu diperhatikan.

d. Merancang sketsa Website.

Dengan sketsa maka seolah telah ada cetak biru dari web yang akan dibangun, memudahkan navigasi, dan manajemen proyek pembangunan web. 
e. Membangun halaman Web.

Berdasar cetak biru yang ada web dibangun dari awal dimulai dengan rancangan sederhana dan dipercanggih bila diperlukan.

f. Memperhatikan aspek kontrol dan auditabilitas.

Dalam sistem yang berbasis komputer yang berbasis web/internet termasuk di dalamnya maka potensi risiko semakin besar, risiko yang makin besar mendorong perlunya kontrol yang memadai dan memperhatikan kontrol tersebut dijalankan dengan sungguh-sungguh. (Sanyoto, 2003:153) Transaksi yang dilakukan hendaknya melalui pengamanan yang cukup dengan melakukan penelahan dengan jasa web hosting yang akan digunakan serta transaksi yang dilakukan harus menyediakan jejak (trail) sehingga memungkinkan fungsi audit dapat dijalankan dengan baik.

Untuk langkah ke-4 ini dapat juga mempergunakan jasa pembangun web bila dana untuk itu tersedia.

5. Menjalankan bisnis berbasis Web/Internet.

a. Menentukan web hosting

Penentuan web yang telah dibangun untuk ditempatkan penting dan hal yang harus diperhatikan adalah fasilitas yang disediakan oleh penyedia jasa web hosting serta memperhatikan perjanjiannya.

b. Akuntansi

Pengelolaan akuntasi manajemen (untuk kebutuhan internal) maupun akuntansi keuangan (untuk kebutuhan eksternal) untuk perusahaan yang berbasis web/internet harus mengikuti standar akuntansi yang telah ditetapkan.

c. Kepemimpinan

Aspek kepemimpinan menjadi sangat penting karena dalam bisnis yang bebrbasis web bagaimana memotivasi dan membuat pekerja lainnya berinisiatif menjadi kunci sukses.

d. Komunikasi

Komunikasi pada bisnis berbasis web mau tidak mau memaksa karyawan untuk mempelajari dan menggunakan teknologi yang tersedia untuk berkomunikasi. Perlu adanya disiplin baru, misalnya dalam waktu penentuan pengecekan surat masuk, waktu rapat bersama, dan hal lainnya yang nantinya akan menjadi budaya perusahaan. Komunikasi yang baik dapat memungkinkan penyimpangan terdeteksi secara dini bahkan mencegah terjadinya penyimpangan.

\section{PENUTUP}

\section{Simpulan}

Membangun bisnis yang berbasis web/internet dari awal lebih baik karena mengurangi penyesuaian yang diperlukan. Bila perusahaan telah berjalan dan hendak dibuatkan unit berbasis web atau internet, sebaiknya unit yang berbasis web didirikan secara independen dan bila perlu dibiarkan mengkanibal intinya. 
Langkah pembuatan web menyangkut selain aspek teknikal juga kontrol dan auditabilitas. Menjalankan bisnis berbasis web/internet atau disebut juga $e$-Business perlu memperhatikan jasa web hosting, aspek akuntansi, kepemimpinan, dan komunikasi.

\section{DAFTAR PUSTAKA}

Afuah, Allan dan Christopher L. Tucci. 2003. Internet Business Models and Strategies $2^{\text {nd }}$ Edition. New York: McGraw Hill.

Eisenmann, Thomas R., Roger Hallowell, dan Mary Tripsas. 2002. Internet Business Models, Text, and Cases. New York: McGraw Hill-Irwin.

Gondodiyoto, Sanyoto dan Idris Gautama So. 2003. Audit Sistem Informasi: Pendekatan Konsep. Jakarta: PT Media Glbal Edukasi.

Hisrich, Robert D., dan Michael P. Peters. 2002. Entrepreneurship. $5^{\text {th }}$ Edition. Singapore: McGraw Hill Higher Education.

Hitt, Michael A., R. Duane Ireland, dan Robert E. Hoskisson. 2001. Strategic Management Competitiveness and Globalization Concepts. South Western College Publishing.

Reding, Elizabeth Eisner. 2001. Building an e-Business from the Ground Up. New York: McGraw Hill-Irwin.

Sugars, Bradley J. 2002. Billionaire in Training. $1^{\text {st }}$ Edition. Action International Pty Ltd, Brisbane

2000. Instant Cashflow the Key to Multiplying Your Business Profits. $2^{\text {nd }}$ Edition. Singapore: Action International (Asia) Pte.Ltd,

Tjager, I Nyoman, F. Antonius Alijoyo, Humprey R. Djemat, dan Bambang Soembodo. 2003. Corporate Governance Tantangan dan Kesempatan bagi Komunitas Bisnis Indonesia. Jakarta: PT. Prenhallindo. 